\title{
The correlation between maternal hypomagnesemia and preterm labour
}

\author{
Shatha A. Mahmoud, Ikhlas M. Saleh*, Huda H. Khalaf
}

Department of Obstetrics and Gynaecology, Yarmouk teaching hospital, Baghdad, Iraq

Received: 30 May 2016

Accepted: 01 July 2016

*Correspondence:

Dr. Ikhlas M. Saleh,

E-mail: drikhlas2007@gmail.com

Copyright: (c) the author(s), publisher and licensee Medip Academy. This is an open-access article distributed under the terms of the Creative Commons Attribution Non-Commercial License, which permits unrestricted non-commercial use, distribution, and reproduction in any medium, provided the original work is properly cited.

\begin{abstract}
Background: Preterm birth is defined as all births before 37 weeks completed, which is a major cause of neonatal death and significant cause of long term loss of human potential amongst survivors. The objective of this study was to verify the correlation between low maternal serum magnesium level and preterm delivery.

Methods: one hundred patients who admitted into the labour room of the hospital due to preterm labour $\left(28-36^{+6}\right.$ weeks of gestation) whose etiology could not be explained by etiological factors were enrolled in this prospective case-control study during the period from June 2013 to June 2014. And another 80 women of comparable gestational age who were referred to the consultation clinic of our hospital for achieving prenatal care or for causes other than preterm labour, provided only those whose birth occurred after $37^{\text {th }}$ week considered as a control group. Serum magnesium level was measured in both groups.

Results: Women in preterm labour had a significantly reduced serum magnesium level (mean $1.552 \mathrm{mg} / \mathrm{dl}$ with a S.D. of 0.658 versus $1.81 \mathrm{mg} / \mathrm{dl}$ with a SD of 0.735$)$ for those delivered at term $(\mathrm{p}<0.032)$. Number of patients with Preterm labour who gave of history of muscle cramps were significantly greater than those delivered at term $(\mathrm{p}<0.00193)$. Percentage of patients with preterm labour belonging to low socio-economic class was significantly higher than the upper and middle socio-economic classes $(\mathrm{p}<0.041)$.

Conclusions: Serum magnesium level can be used as a predicting tool for idiopathic preterm labour.
\end{abstract}

Keywords: Preterm labour, Serum magnesium level

\section{INTRODUCTION}

Preterm birth is defined as delivery of the baby before 37 completed weeks of pregnancy to the limit of viability as 24 weeks, births before 32 weeks of gestation (2\% of all births) account for most neonatal deaths and disorders. ${ }^{1,2}$ Preterm birth is a major cause of neonatal mortality, which is estimated to be at least $50 \%$ of all neonatal deaths, with the highest rates of health care costs due to hospitalization of woman with preterm labor and the expenses of long-term care of preterm birth. ${ }^{3-5}$ The incidence in the developed world is $7-12 \% .^{6}$

Approximately $45-50 \%$ of preterm births are idiopathic, $30 \%$ are related to preterm rupture of membranes
(PROM) and another $15-20 \%$ is attributed to medically indicated or elective preterm deliveries. ${ }^{7,8}$

Other causal factors include infection e. g. Urinary tract infection and bacterial vaginosis. ${ }^{9}$ In addition, ascending intrauterine infection and inflammation with secondary premature cervical shortening. ${ }^{10}$

Beside these etiologies, preterm labour may be due to a biochemical alteration of body function at the cellular level stating emphasis on trace elements such as magnesium, which is the second most abundant intracellular cation after potassium. ${ }^{11,12}$ It plays a number of vital physiological and biochemical roles; intracellular ionized magnesium is essential for nerve conduction and 
muscle contraction. ${ }^{13}$ The inhibitory effect of magnesium on preterm labour is attributed to antagonism of calcium mediated uterine contractions. ${ }^{14}$

\section{METHODS}

A cross sectional case-control study had been carried out in the department of obstetrics and gynecology, Yarmouk teaching hospital/Baghdad-Iraq; for 12 months. A total of 180 women were enrolled and divided into two groups.

\section{Group l (study)}

Consisted of 100 patients who admitted in labour room of the hospital due to preterm labour which could not be explained by the known etiological factors (idiopathic).

\section{Group II (control)}

Consisted of 80 women with uncomplicated pregnancy of comparable gestational age that referred to the consultation clinic of our hospital for achieving prenatal care or for causes other than preterm labor, only women whose delivery occurred after $37^{\text {th }}$ week considered as a control group.

\section{Every patient underwent full evaluations that include}

Detailed and comprehensive history taking with emphasis on

- Demographic data: Name, age, gravidity, parity, socioeconomic class and employment status

- Gestational age: determined by date of last menstrual period or early ultrasound examination.

\section{History of muscle cramps during pregnancy}

- Physical examination: systemic and local (speculum and digital vaginal examination)

- Investigations: include full blood count, general urine examination, and random blood glucose.

\section{Inclusion criteria}

Age ( $>18$ years and $<40$ years), singleton gestation, intact fetal membranes, preterm onset of labour (between 28 and $36+6$ weeks of gestation) and Bishop score $\geq 7$.

\section{Exclusion criteria}

Previous history of preterm delivery; recurrent UTI, preeclampsia, polyhydramnios, antepartum hemorrhage, intrauterine death, premature rupture of membranes and any significant medical or surgical illness.

Blood samples from the patient were drawn after taking written consent into syringe, sent to laboratory of the hospital immediately. The quantitative assessment of serum magnesium levels was done in the biochemistry unit by using Xylidyl blue colorimetric method (manufactured by Egyptian company for biotechnology (S.A.E). ${ }^{15}$

Statistical analysis of the obtained data was done by Student's t-test for comparison of means.

P- Value considered significant when it is equal to or less than 0.05 and considered highly significant when it is equal to or less than 0.005 .

\section{RESULTS}

The mean age in group I was 24.31 \pm 5.77 years (range 18 to 39 years) while in group II it was $26.52 \pm 5.74$ years (range 18 to 40 ). No statistically significant difference was observed in patients' age between the two groups; $(\mathrm{P}=0.183)$. According to obstetrical history of parity and miscarriage, no statistically significant difference was observed between the two groups $(p=0.226,0.203$ respectively) as in Table 1 . There was no significant difference in employment status $(\mathrm{p}=0.58)$ while for socioeconomic classes, there was statistically significant difference between two groups $(\mathrm{P}=0.041)$ as Table 2 .

Table 1: The obstetrical history in both groups.

\begin{tabular}{|c|c|c|c|c|}
\hline Variable & & coup I & Group II & P-value \\
\hline \multirow{2}{*}{ Parity } & 0 & 35 & 23 & \multirow{2}{*}{0.226} \\
\hline & 1 or more & 65 & 57 & \\
\hline \multirow{2}{*}{ Miscarriage } & yes & 17 & 13 & \multirow{2}{*}{0.203} \\
\hline & No & 73 & 67 & \\
\hline
\end{tabular}

Table 2: Social characteristics in both groups.

\begin{tabular}{|lcll|}
\hline Variable & Group I & Group II & P-value \\
\hline Employment & & & \\
\hline Housewife & 85 & 71 & 0.58 \\
\hline Employed & 15 & 9 & \\
\hline Socioeconomic classes & & \\
\hline High & 4 & 4 & \\
\hline Moderate & 44 & 48 & 0.041 \\
\hline Low & 52 & 28 & \\
\hline
\end{tabular}

Regarding history of muscle cramps, there was statistically highly significant difference between the two groups $(\mathrm{P}=0.00193)$ as in Table 3.

The mean serum magnesium level in group I was found to be $1.552 \mathrm{mg} / \mathrm{dl}$ with a S.D. of 0.658 where as in group II it was $1.81 \mathrm{mg} / \mathrm{dl}$ with a SD of 0.735 .

Table 3: History of muscle cramps in both groups.

\begin{tabular}{|llll|}
\hline Variable & Group I & Group II & P-value \\
\hline Muscle cramps & & & \\
\hline Positive & 73 & 42 & 0.00193 \\
\hline Negative & 27 & 38 & \\
\hline
\end{tabular}




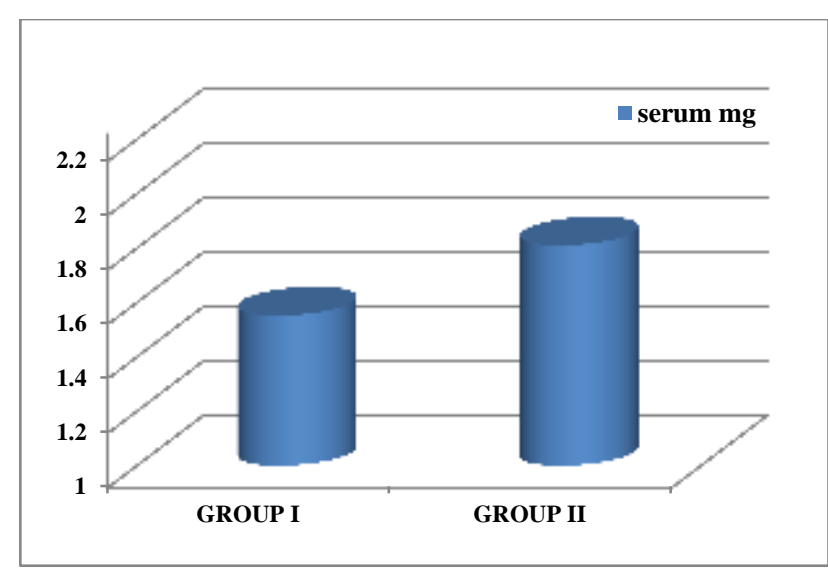

Figure 1: comparison of serum magnesium levels in both groups.

The difference between the two groups was found to be statistically significant $(\mathrm{p}<0.032)$ as in Figure 1.

The mean serum magnesium level was divided according to gestational age into three groups as in Table 4 .

Table 4: Serum magnesium levels at different gestational age.

\begin{tabular}{|llll|}
\hline $\begin{array}{l}\text { Gestational } \\
\text { age (weeks) }\end{array}$ & $\begin{array}{l}\text { Group I } \\
(\text { mean } \pm \text { SD })\end{array}$ & $\begin{array}{l}\text { Group II } \\
(\text { mean } \pm \text { SD })\end{array}$ & $\begin{array}{l}\text { P- } \\
\text { value }\end{array}$ \\
\hline $28-30$ & $1.843 \pm 0.70$ & $1.84 \pm 0.512$ & 0.992 \\
\hline $31-33$ & $1.309 \pm 0.369$ & $1.82 \pm 0.54$ & 0.016 \\
\hline $34-36$ & $1.23 \pm 0.28$ & $1.73 \pm 0.416$ & 0.035 \\
\hline
\end{tabular}

\section{DISCUSSION}

The main focus in the current study to compare the serum magnesium level in preterm birth and in those who had a term delivery, many records findings have augmented measuring magnesium level as a predictor for preterm birth. The exact cause of hypomagnesaemia in patient of preterm birth is unknown but individualized and socioeconomic factors have been blamed. ${ }^{16}$

In this study, the age of the women, their parity, history of miscarriages and employment status were comparable in study and control groups, which exclude their effect on the result; similar to Kamal's et al and Shahid et al findings. ${ }^{17,18}$

The number of preterm labour cases belong to lower socioeconomic class was significantly higher than high or middle classes, the same as Sharma A et al findings. ${ }^{19}$ On the contrary Khani et al demonstrated non- significant increase in preterm labour among low socioeconomic class women may be due to the smaller sample size in his study when he took only 40 pregnant women. ${ }^{20}$

This result reflect the real figure in our society, as the high social class women attend governmental hospital when they have preterm labour because intensive neonatal care units are not available in private hospitals.

This increase in preterm labour in low socioeconomic class may be attributed to poor prenatal care, stressful life style and nutritional deficiency of trace elements including magnesium.

We found that a history of muscle cramps were more in the study group than in control group like Hantoushzadeh et al finding, as hypomagnesaemia leads to neuromuscular hyper excitability resulting in muscle cramps and uterine hyperactivity. ${ }^{21}$

The mean magnesium level was $1.552 \pm 0.658 \mathrm{mg} / \mathrm{d}$ in those with preterm labour and $1.81 \pm 0.735 \mathrm{mg} / \mathrm{dl}$ in those with term delivery, this result is supported by the findings of many investigators, Puspo and Jagdish et al found serum magnesium level in preterm labour $1.67 \pm 0.23$ $\mathrm{mg} / \mathrm{dl}^{22}$ Begum et al also found serum magnesium $1.77 \pm 0.36$ in preterm labour. ${ }^{23}$ Kehinde et al found mean serum magnesium level $1.73 \pm 0.4$ versus $1.93 \pm 0.4$ $\mathrm{mg} / \mathrm{dl} .^{24}$

Uludağ et al found basal serum magnesium was significantly lower in successful preterm labour group in whom contractions ceased with magnesium sulfate tocolysis 1.6 versus $1.9 \mathrm{mg} / \mathrm{dl}$ for unsuccessful preterm labour group whose contractions increased and delivered preterm despite magnesium sulfate tocolysis ( $\mathrm{p}$ value $<0.001$ ) and a cut off value of $<1.75 \mathrm{mg} / \mathrm{dl}$ had a significant predictive value for better identifying a positive response to tocolytic magnesium sulfate. ${ }^{25}$

Regarding magnesium level at different gestational age, we found that in 28-30 weeks, although it was higher in group II but statistically non-significant unlike Shakura et al who found it highly significant, probably because of different dietary habits in our society, while it was lower in group I compared to group II in gestational age 31-33 and 34-36 weeks and the difference was statistically significant like Shakura et al, which may due to increased demand with the advance of pregnancy. ${ }^{26}$

We observed that there was a decrease in serum magnesium with progression of pregnancy in both groups in agreement with observation of other investigators. ${ }^{27,28}$

A study conducted by Cunze et al. on magnesium and calcium concentration in the pregnant and non-pregnant myometrium, concluded that a low magnesium concentration in the pregnant human myometrium could be a cause of preterm labour. ${ }^{29}$

Further studies have demonstrated that prophylactic oral magnesium supplementation to patient at risk of preterm labour was successful in lowering the preterm delivery rate and intake should be sufficient to maintain serum magnesium level at the range of $2.0-3.5 \mathrm{mg} / \mathrm{dl}^{30-32}$ 


\section{CONCLUSION}

Estimation of serum magnesium levels may be a useful parameter in pregnancy especially in women at high risk of preterm labour mainly in countries with poor resources since it is cheap investigation.

\section{ACKNOWLEDGEMENTS}

The Authors would like to express their gratitude to members of biochemistry unit of Yarmouk teaching hospital laboratory and Dr. Omar M. Shakir who performed the statistical analysis of the obtained data.

\section{Funding: No funding sources}

Conflict of interest: None declared

Ethical approval: The study was approved by the Institutional Ethics Committee

\section{REFERENCES}

1. Tucker J, McGuire W. Epidemiology of preterm birth. BMJ. 2004;329:675-8.

2. Goldenberg RL, Rouse DJ. Prevention of premature birth. New England Journal of Medicine. 1998;5:313-20.

3. Lawn JE, Kerber K, Enweronu-Laryea C, Cousens S. 3.6 million neonatal deaths - what is progressing and what is not? Semin Perinatol. 2010;34:371-86.

4. Terzidou V, Phillip RB. Preterm labour. Curr Opin Obstet Gynecol. 2002;14:105-13.

5. McLaurin KK, Hall CB, Jackson EA, Owens OV, Mahadevia PJ. Persistence of morbidity and cost differences between late-preterm and term infants during the first year of life. Pediatrics. 2009;123:6539.

6. Bennett P, Keith E. Dewhurst $s$ Textbook of Obstetrics and Gynaecology. $8^{\text {th }}$ ed. Black well publishing. Malaysia; 2011:28:338-354.

7. Haas DM. Preterm birth in clinical evidence. London: BMJ Publishing Group; 2006.

8. Pennell CE, Jacobsson B, Williams SM, Buus RM, Muglia LJ, Dolan SM, et al. Genetic epidemiologic studies of preterm birth: guidelines for research. Am J Obstet Gynecology. 2007;196:107-18.

9. Gravett MG, Rubens CE, Nunes TM. Global report on preterm birth and stillbirth (2 of 7): discovery science. BMC Pregnancy Childbirth. 2010;S210:Suppl 1.

10. Lee SE, Romero R, Park CW, Jun JK, Yoon BH. The frequency and significance of intra-amniotic inflammation in patients with cervical insufficiency. Am J Obstet Gynecol. 2008;198:e631-638.

11. Whitney EN, Cataldo CB, Rolfes SR. $6^{\text {th }}$ ed. Understanding Normal and Clinical nuttrition, Belmont, CA: Wadsworth; 1996.

12. Jeroen HF, de Baaij, Hoenderop GJ, Bindels RJM. Magnesium in man: implication for health and disease. Physiological Reviews. 2015;95(1):1-46.
13. Griffin IJ. Encyclopedia of food sciences and nutrition (Second Edition); 2003:3641.

14. Smith R. Parturition. N Engl J Med. 2007;365:27183.

15. Magnesium colorimetric method. CHEMHOUSE, INS 069-1/2, 2005. Available at http://www.chemhousediagnostics.com/files/theme/6 9_MAGNESIUM.pdf.

16. Swain R, Kaplan, Machlis B. Magnesium for the next millennium. South Med J. 1999;92:1040-7.

17. Kamal S, Sharan A, Kumar U, Shahi SK. Serum magnesium level in preterm labour. Indian J Pathol Microbiol. 2003;46(2):271-3.

18. Shahid AR, Hosna AU, Tahmina HZ. Hypomagnesaemia in pregnancy: a predictor of preterm labour. Journal of Dhaka Medical College. 2010;19(1):51-7.

19. Sharma A, Kharb S, Vineeta, Gulati N. Serum magnesium levels in preterm labour in relation to socioeconomic status. Indian Journal of Biochemistry. 1998;13:123-5.

20. Khani S, Shokrzadeh M, Karamoddini PK, Shahmohammadi S. The relationship between maternal serum magnesium level and preterm birth. Pakistan Journal of Biological Sciences. 2010;13:335-9.

21. Hantoushzadeh S, Jafarabadi M, Khazardoust S. Serum magnesium levels, muscle cramps and preterm labour. Int J Gynae Obst. 2007;98(2):153-4.

22. Pushpo D, Jagdish WMA. A study of serum mgnesium level in preterm labour. The $\mathrm{J}$ of Obstet Gynaecol India. 1991;41:269-73.

23. Begum H, Shamsuddin L, Khatun S. Relationship of preterm labour with serum magnesium level. Bangladesh J Obstet Gynaecol. 2004;19(1):3-6.

24. Okunade KS, Oluwole AA, Adegbesan-Omilabu MA. A study on the association between low maternal serum magnesium level and preterm labour. Adv Med. 2014;2014:704875.

25. Uludăg EU, Gözükara IO, Kukur SK, Erkaya S. Maternal magnesium level effect on preterm labour treatment. J Maternal Fetal Neonatal Med. 2014;27(14):1449-53.

26. Shakura B, Arfat W. Serum magnesium levels in preterm labour. Sri Lanka Journal of Obstetrics and Gynecology. 2012;34:37-44.

27. Kurzel RB. Serum magnesium levels in pregnancy and preterm labour. Am J Perinatol. 1991;8(2):11927.

28. Potnis AV, Patel PV, Purandare BN. Magnesium the ignored element during pregnancy. $\mathrm{J}$ of Obst and Gynae of India. 1977;27:343-5.

29. Cunze T, Rath W, Osmer R, Martin M, Warneke G, Kuhn W. Magnesium and calcium concentration in pregnant and nonpregnant myometrium. Int J Obstet Gynaecol. 1995;48:9-13.

30. Kuti V, Balaz M, Morvay F, Vatenka Z, Szekely A. Effect of maternal magnesium supply on spontaneous abortion and premature birth and on intrauterine fetal development- experimental 
epidemiological study. Magnesium Bulletin.1981;3:73-9.

31. Conradt A, Weidinger H. The importance of beta mimetics and magnesium for pregnancy. Z Geburtshilfe Perinatol. 1983;187(3):127-37.
32. Spatting L. Magnesium in obstetrics and gynaecology. Gynakol Geburtshilfliche Rundsch. 2004;33:85-91.

Cite this article as: Mahmoud SA, Saleh IM, Khalaf HH. The correlation between maternal hypomagnesemia and preterm labour. Int J Reprod Contracept Obstet Gynecol 2016;5:2571-5. 